\title{
Best Management Practices for Temperate and Tropical/Subtropical Fruit Crops in Florida: Current Practices and Future Challenges
}

\author{
Jeffrey G. Williamson ${ }^{1,3}$ and Jonathan H. Crane ${ }^{2}$
}

ADDITIONAL INDEX WORDS. fertilizer, irrigation, fertigation, plant nutrition

Summary. A wide variety of temperate, subtropical, and tropical fruit crops are grown commercially in Florida. Farm size ranges from large commercial operations exceeding 100 acres to small 1 - or 2 -acre "estate" farms. Irrigation and fertilization practices vary widely with crop, soil type, and management philosophy. However, many growers are adopting practices such as microirrigation, fertigation, and other technologies, which, if properly used, should reduce water and fertilizer inputs and minimize leaching and runoff of fertilizers and pesticides. Although fertilizer and irrigation recommendations exist for major crops such as avocado (Persea americana), mango (Mangifera indica), and blueberry (Vaccinium spp.), there is little research-based information specific to Florida for many minor crops, including muscadine (Vitis rodundifolia), blackberry (Rubus spp.), sapodilla (Manilkara zapota), guava (Psidium guajava), papaya (Carica papaya), and others. Even where recommendations exist, refinement of irrigation and fertilization practices is needed because of changes in technology.

Temperate Fruit. Temperate fruit crops grown commercially in Florida include blueberry, stone fruit [(peach (Prunus persica), nectarine (P. persica var. nectarina), plum (Prunus salicina)], muscadine grape, brambles (primarily blackberry), and persimmon (Diospyroskaki). Of these, blueberry has demonstrated the most growth and expansion during the last decade. Harvested blueberry acreage has more than doubled from 1200 acres in 2000 to 3000 acres in 2008 [U.S. Department of Agriculture (USDA), 2008]. Total production and yield per acre have also increased significantly. The total production for the state was estimated at 9.8 million pounds in 2008 compared with 3.3 million pounds for 2000. In 2008, the industry's value was estimated at $\approx \$ 52$ million, an increase of over $\$ 12$ million from the previous year (USDA, 2008). With the continued development of new plantings, further growth and expansion of blueberry acreage is expected for the foreseeable future. Blueberry farm sizes range from less than 5 acres to over 100 acres. Full-time blueberry

We thank the Florida Agricultural Experiment Station for providing funding.

${ }^{1}$ Horticultural Sciences Department, IFAS, University of Florida, P.O. Box 110690, Gainesville, FL 326110690

${ }^{2}$ Tropical Research and Education Center, IFAS, University of Florida, Homestead, FL

${ }^{3}$ Corresponding author. E-mail: jgrw@ufl.edu. growers usually have more than 20 acres in production. Farms are scattered throughout peninsular Florida. Leading counties for blueberry production are Alachua and Polk, but significant acreage is located in Hillsborough, Hernando, Hardee, and throughout central and northcentral Florida (Williamson et al., 2000). Most blueberry growers use deep wells, which access the Floridian Aquifer for irrigation. Irrigation for freeze protection is needed for reliable production in most areas of Florida.

Commercial acreage of stone fruit in Florida is limited to a few hundred acres, but the potential for growth of this profitable, alternative crop is high (Andersen et al., 2000). The area with the most potential for growth is central and north-central Florida where some winter chilling occurs, yet very early-season production is possible. Peaches are also susceptible to freeze injury and may require irrigation for cold protection. Muscadine grape and persimmon are each limited to a few hundred acres in north-central and central Florida (Andersen et al., 2000).

Increased acreage (especially blueberry) in recent years along with rapid urbanization has resulted in greater competition between agriculture and the urban sector for water. Many growers are using dual systems: low-volume for routine irrigation and overhead irrigation for freeze protection. Freeze protection of flowers and young fruit is essential for reliable production of early-flowering crops such as blueberry and stone fruit. Freeze protection often requires large amounts of water for the duration of the freeze(s) (Lyrene and Williamson, 2006).

TROPICAL AND SUBTROPICAL FRUIT. Tropical and subtropical fruit production in Florida covers $\approx 13,000$ acres and is located primarily in MiamiDade County ( $\approx 85 \%$ of the acreage) with small acreages in Lee, Palm Beach, Brevard, Broward, Collier, Indian River, St. Lucie, Martin, Charlotte, Pasco, and Sarasota counties (USDA, 2009). Gross crop value in MiamiDade County alone is estimated at more than $\$ 73$ million annually with an economic impact exceeding $\$ 137$ million (Degner et al., 2002). Crops grown commercially include avocado, mango, banana (Musa hybrids), carambola, guava, jackfruit (Artocarpus heterophyllus), longan (Nephelium longana), lychee (Litchi chinensis), mamey sapote (Pouteria sapota), papaya, passion fruit (Passiflora edulis, P. edulis forma flavicarpa, Passiflora hybrids), pitaya (Hylocereus spp. and hybrids), sapodilla, and sugar apple (Annona squamosa). The average size farm is 27 acres, but the most common size orchard (greater than $57 \%$ )

\begin{tabular}{llll}
\hline $\begin{array}{l}\text { Units } \\
\begin{array}{l}\text { To convert U.S. to SI, } \\
\text { multiply by }\end{array}\end{array}$ & U.S. unit & SI unit & $\begin{array}{l}\text { To convert SI to U.S., } \\
\text { multiply by }\end{array}$ \\
\hline 0.4047 & $\mathrm{acre}(\mathrm{s})$ & $\mathrm{ha}$ & 2.4711 \\
0.3048 & $\mathrm{ft}$ & $\mathrm{m}$ & 3.2808 \\
3.7854 & $\mathrm{gal}$ & $\mathrm{L}$ & 0.2642 \\
9.3540 & $\mathrm{gal} / \mathrm{acre}$ & $\mathrm{L} \cdot \mathrm{ha}^{-1}$ & 0.1069 \\
2.54 & inch(es) & $\mathrm{cm}$ & 0.3937 \\
25.4 & inch(es) & $\mathrm{mm}$ & 0.0394 \\
0.4536 & $\mathrm{lb}$ & $\mathrm{kg}$ & 2.2046 \\
1.1209 & $\mathrm{lb} / \mathrm{acre}$ & $\mathrm{kg} \cdot \mathrm{ha}{ }^{-1}$ & 0.8922 \\
1 & $\mathrm{ppb}$ & $\mu \mathrm{g} \cdot \mathrm{L}^{-1}$ & 1 \\
1 & $\mathrm{ppm}$ & $\mathrm{mg} \cdot \mathrm{L}^{-1}$ & 1
\end{tabular}

Hortlechnology · February $201020(1)$ 
is between 1 and 9 acres (Degner et al., 2002; Migliaccio et al., 2006; USDA, 2009 ). Demographically $\approx 67 \%$ of the commercial tropical fruit growers are part-time producers and have limited agricultural background (Migliaccio et al., 2006; Tropical Research and Education Center, 2005; USDA, 2009). The other $33 \%$ are full-time producers with educational and/or experiential backgrounds in agriculture.

The sustainability of tropical/ subtropical fruit production in Florida is influenced by economic, marketing, technological, environmental, and social factors (Edwards, 2005a, 2005b, 2008; Edwards et al., 2008a, 2008b; Migliaccio, 2007). The surficial Biscayne aquifer is the main source of water used by agriculture, urban, and the natural areas (e.g., Everglades National Park, Biscayne Bay National Park) (Migliaccio, 2007). This limestone and sand-based aquifer is highly permeable and therefore potentially subject to pollutants from agricultural and urban activities. The demand for water from this aquifer has intensified as a result of climate variability, rapid urbanization, and natural system protection requirements. The main sources of water for recharging the aquifer are rainfall and a number of springs at the northern end of the surficial aquifer system above Lake Okeechobee. Annual rainfall in the marine subtropical environment in southern Florida averages $\approx 63$ inches.

A relatively recent groundwater quality survey of six public supply wells in the agricultural area of Miami-Dade County found few samples with elevated nitrate levels but detected 15 different pesticides at levels below drinking water standards (Bradner et al., 2004). In a more detailed study, the magnitude and frequency of nitrate and phosphorus $(\mathrm{P})$ leaching in several avocado, 'Tahiti' lime (Citrus latifolia), and carambola (Averrhoa carambola) orchards were investigated in southern Miami-Dade County (B. Schaffer and S. O'Hair, unpublished data). Groundwater monitoring of all orchards after fertilizer applications revealed total Kjeldahl nitrogen, ammonium nitrogen $\left(\mathrm{NH}_{4}-\mathrm{N}\right)$, and nitrate-nitrogen $\left(\mathrm{NO}_{3}-\mathrm{N}\right)$ concentrations at or below $1.9,0.2$, and $22.4 \mathrm{mg} \cdot \mathrm{L}^{-1}$, respectively. On six occasions, $\mathrm{NO}_{3}$ - $\mathrm{N}$ levels exceeded $10 \mathrm{mg} \cdot \mathrm{L}^{-1}$ after times of excess rain. This is above the U.S.
Environmental Protection Agency limit for water used for human consumption (U.S. Environmental Protection Agency, 1989). Groundwater total phosphorus concentrations within all orchards were generally below $60 \mathrm{ppb}$; however, inflow wells (upstream) total phosphorus (I-TP) concentrations went as high as 140 $\mathrm{ppb}$ on four occasions. Total P concentrations within avocado, lime, and carambola orchards were below I-TP concentrations $\approx 50 \%, 38 \%$, and $45 \%$ of the time, respectively. Orthophosphate $(\mathrm{OP})$ concentrations within all orchards were below $19 \mathrm{ppb}$ and below inflow well OP concentrations $38 \%$ to $60 \%$ of the time. However, there was usually not a significant amount of leaching of fertilizers into the groundwater in the experimental fields compared with $\mathrm{NO}_{3}-\mathrm{N}$ values obtained from inflow (upstream) wells. This was confirmed by the fact that fertilizer treatments used in this investigation (increasing $\mathrm{N}-\mathrm{P}-\mathrm{K}$ application rates) did not affect leaching of $\mathrm{NO}_{3}-\mathrm{N}$ into the groundwater. There was no significant leaching of $\mathrm{NH}_{4}-\mathrm{N}$ or $\mathrm{P}$ into the groundwater.

The major issues and challenges with sustainable cultural practices for both temperate and tropical fruit crops include: 1) managing irrigation to meet plant water needs and avoid leaching of fertilizers into the aquifer; 2 ) reducing fertilizer use as irrigation management becomes more precise in mainly wetting the rhizosphere; and 3 ) continuing to improve pest management systems and decreasing the need for pest control substances with issues of environmental safety. Interestingly, $78 \%$ of the commercial fruit growers recently surveyed indicated they would implement best management practices (BMPs) under the Florida Department of Environmental Protection presumption of compliance incentive (Migliaccio et al., 2006). However, 66\% reported that they would not spend more than $\$ 500$ to implement BMPs suggesting cost-sharing will be an essential component for some producers to implement BMPs.

\section{Nutrient and irrigation management}

Blueberry. Southern highbush blueberry $(\mathrm{SHB})$ comprises the majority $(\approx 3000$ acres $)$ of commercial blueberry acreage in Florida. The following discussion is for $\mathrm{SHB}$ as opposed to rabbiteye blueberry ( Vaccinium virgatum), which has different management requirements and is primarily grown in small noncommercial plantings through northern and north-central Florida. SHB are grown commercially throughout Florida with the exception of the western panhandle area and the southern most part of the peninsula. SHB are typically grown in Florida using one of the following soil management systems: l) soil culture-plants are planted directly in a nonamended soil that is naturally suited for blueberries (rare in Florida); 2) amended soil cultureplants are planted in soil that is highly amended with pine bark or other organic soil amendment $(30 \%$ to $50 \%, \mathrm{v} / \mathrm{v}$ ) to increase soil organic matter, increase porosity, and help lower soil $\mathrm{pH}$ (usually an additional 3 to 4 inches of pine bark is added as mulch after planting); and 3 ) pine bark bed culture-plants are planted directly in 6 to 8 inches of pine bark on top of native soil. The bark is arranged in solid beds $\approx 3 \mathrm{ft}$ wide down the row (very common in Florida).

Pine bark bed culture is the most common production system for $\mathrm{SHB}$ in Florida and typically results in shallow root systems that are restricted to the pine bark layer. This substrate has marginal water- and nutrient-holding capacities, especially when new or fresh bark is used. Together, the shallow root system and the physical and chemical properties of pine bark create a need for frequent irrigation and frequent light fertilizations if conventional fertilizers are used. Without careful management, more water than is required to wet the bark profile is applied during irrigation events. In the case of microor drip irrigation, in which application rates per unit of surface area are greater than with overhead, much of the water may move below the pine bark layer before it is absorbed by plants (J.G. Williamson, personal communication). In summary, pine bark beds should be managed very differently from soil or amended soil and the physical properties of pine bark change as the bark ages and decomposes with fresh bark being the most difficult to manage.

Fertilizer requirements for SHB will depend on the soil management 
systems used. Because the most common production method in Florida is pine bark bed culture, the blueberry root system is usually limited to the top 6 to 8 inches (depth of the bark layer) of growing substrate. Higher nitrogen $(\mathrm{N})$ rates are needed in pine bark culture than with soil culture for several reasons: 1) fresh pine bark has a relatively high carbon to $\mathrm{N}$ ratio and some $\mathrm{N}$ is temporarily unavailable for plant uptake; 2) pine bark (especially fresh bark) does not retain water or bind anions or cations as well as many soils do and nutrient leaching may occur with frequent irrigations; and 3 ) roots of blueberry grown in pine bark beds tend to stay in the pine bark layer and do not grow in the soil below the bark. The result is shallow rooting, which in turn results in the need for frequent irrigations, which can move the nutrients below the shallow root system. Although no formal survey has been conducted, the majority of growers probably apply $\mathrm{N}$ within the suggested range of 150 to $225 \mathrm{lb} /$ acre per year. Research is needed to better define $\mathrm{N}$ requirements in pine bark bed culture and determine if there are advantages to pine bark-amended soils over pine bark beds with respect to fertilization and irrigation practices. Many growers routinely use leaf nutrient analyses to monitor fertilizer programs. Experienced growers use plant vigor and overall appearance along with leaf and soil analyses to fine tune their fertilization programs. Soil samples are used to monitor soil $\mathrm{pH}, \mathrm{P}$, potassium $(\mathrm{K})$, calcium, and magne$\operatorname{sium}(\mathrm{Mg})$.

Fertilizers are often applied as dry, granular formulations. This is especially true for plantings with only overhead irrigation. Growers tend to use blended fertilizers, and they use leaf analysis as a guide to make adjustments to their blends or to make supplemental applications of a particular element(s). However, fertilizer type and method of application may depend on irrigation practices. Fertigation is often used to apply at least a portion of the fertilizer for microirrigated plantings. Where dry, granular fertilizers are used, slow-release or controlled-release fertilizers are often used as a component of the overall nutritional program to reduce leaching of nutrients below the root zone. However, in late fall, slowly released $\mathrm{N}$ may not be desirable because plants enter dormancy.

Blueberries prefer ammonium to nitrate, so most blueberry fertilizers have relatively small amounts of nitrate (Williamson et al., 2006). The $\mathrm{N}$ component is often from ammonium salts or urea, a portion of which may be coated with sulfur $(S)$ (slow release) or with polymers (controlled release). The two most common carriers of $\mathrm{N}$ are urea and ammonium sulfate; however, nitrate is sometimes used in combination with other $\mathrm{N}$ forms if the substrate $\mathrm{pH}$ is low and if nitrate is only a small part of the total $\mathrm{N}$ applied (Krewer and Nesmith, 2004; Williamson et al., 2006). Until recently, almost all fertilizers have been applied as dry, granular, blended formulations. Granular formulas vary, but a common analysis for the industry is $12 \mathrm{~N}-1.8 \mathrm{P}-6.6 \mathrm{~K}$ (Krewer and Ruter, 2005). Fertigation is becoming more common with the increased use of microirrigation. Application rates and timing vary from farm to farm and whether plants are grown in soil or in pine bark beds. Annual N recommendations for mature blueberry plants grown in soil in Florida are 90 to $120 \mathrm{lb} /$ acre $\mathrm{N}$ divided into at least five equal applications beginning in April and ending in September (Williamson and Lyrene, 1995). Exact beginning and ending dates will vary with location in Florida and length of the growing season. For pine bark bed culture, the $\mathrm{N}$ recommendation is considerably higher than for soil, 150 to $225 \mathrm{lb} /$ acre $\mathrm{N}$ per year divided into eight to 10 applications beginning in late February and ending in early October (Williamson et al., 2006). A recent study (Williamson and Miller, 2009) indicated that fertilizer rates recommended for soil systems were inadequate for pine bark bed culture. The same observation has been made by numerous blueberry growers throughout Florida.

Blueberry is shallow-rooted and susceptible to drought. Depending on rainfall patterns, irrigation may be needed at any time during the year; the most critical periods usually are during fruit development and through summer and early fall during the major vegetative growth flush and when transpiration is high. Generally, it is believed that blueberry requires $\approx 1.0$ to 1.5 inches $(27,000$ to 40,500 gal/acre) of water per week during the time of most growth (Braswell et al., 2004; Himelrick et al., 1995; Williamson et al., 2006). Brightwell and Austin (1980) suggested a range from 1.0 to 1.8 inches per week. Water requirements generally increase as leaf canopies develop and fruit growth and development occurs. Williamson and Lyrene (1995) suggested 0.3 to 1.3 inches of water per week depending on time of year and stage of crop development. In Chile, Holzapfel et al. (2004) found that $100 \%$ evapotranspiration (ET) replacement with microsprinklers or drip resulted in yields greater than $33 \%$ or $66 \%$ ET replacement. However, there was no apparent advantage to $130 \%$ over $100 \%$ ET replacement. Overall, yields with microsprinklers were higher than drip treatments with the same amount of water applied, suggesting that a microsprinkler was more efficient than drip.

Many blueberry growers subscribe to private weather services or have weather stations to monitor temperature, wind speed, dew point, and ET. However, grower decisions on when to irrigate, and how much to irrigate, are largely subjective. Unfortunately, soil moisture monitoring devices have not been reliable in pine bark substrates. A recent study by Dourte (2007) suggests that growers may overirrigate pine bark bed systems. In that study, plants that were irrigated daily for a short duration (in the absence of rain) were compared with a nearby grower field where plants were irrigated for longer durations but at less frequent intervals, usually every 2 or $3 \mathrm{~d}$. During the course of the study, less water was applied to the daily, short-duration plants with no apparent reduction in growth or yield when compared with the grower field. It is likely that there is a tendency for blueberry growers using the pine bark bed production system to apply more water than is needed to wet the bark profile during a given irrigation event.

Most SHBs are currently grown on pine bark beds where their root systems are limited to the depth of the pine bark bed (a few inches). Therefore, irrigations should be scheduled frequently and for short durations, applying only enough water to wet the root profile. Williamson and Lyrene (1995) suggested irrigating two to three times per week during periods 
of no rain and high evaporative demand. Recent research suggests that even more frequent, short-duration irrigations may be more efficient on pine bark bed production systems (Dourte, 2007).

Irrigation systems for blueberry must be equipped to protect against late winter and early spring freezes. Typically this requires high-output, overhead systems capable of supplying up to 0.3 inches of water per hour for several hours (the duration of the freeze), possibly for two or three consecutive nights. The number of freeze events at any given location varies from year to year but can be numerous. Therefore, overhead irrigation is used by essentially all SHB growers in Florida.

Irrigation practices vary with the type of production system used (described previously), plant age, soil profile characteristics, and management philosophy of the blueberry grower. Many older fields are equipped only with overhead systems that provide both routine irrigation needs and freeze protection. Many new plantings are being established with microirrigation systems for routine irrigation needs while also having overhead irrigation for freeze protection. Whether these systems (especially drip) will provide adequate root zone coverage in pine bark substrate as plantings mature is not known. Microsprinklers used in new plantings may be well suited for pine bark and sands amended with pine bark because of large areas of root zone coverage.

Blueberry growers use little irrigation during the winter, especially after leaf drop. Overhead irrigation is usually avoided during flowering (except for cold protection) to reduce the incidence of botrytis flower blight (Botrytis cinerea). The most critical period for irrigation of blueberry is during the fruit development period (February through May in Florida), which often corresponds with the driest period of the year in Florida (Williamson and Lyrene, 1995). Fruit harvesting in a particular field may extend for several weeks with individual harvests at 3- to 4-d intervals. During harvest, overhead irrigation is usually timed immediately after a harvest to minimize the possible negative effects on fruit quality and maximize the effects on berry size (Williamson et al., 2006). A second critical period for irrigation follows summer pruning (June through October) when new growth is occurring, which will determine the potential for next year's crop. During this time, long days and high temperatures put high water demands on the crop. Beginning in October, many growers apply reduced rates of irrigation in an attempt to slow growth and prepare plants for dormancy. In southern growing areas, some growers are using a nondormant production system (Darnell and Williamson, 1997; Obreza et al., 1998). In these cases, higher rates of irrigation are needed during late fall and winter than for the traditional dormant production system.

The pine bark bed system is inherently difficult to manage from an irrigation and fertilization efficiency standpoint. Growers should be aware of the water-holding capacities of the substrate (i.e., pine bark or soil) realizing that the physical and chemical properties of pine bark change as it ages and decomposes. Growers should know the depth of the plant roots and about how much water is needed to wet the soil profile occupied by the root system. In many cases, especially in pine bark bed production, frequent but shorter-duration irrigation events may be needed to maximize water use and minimize nutrient loss. However, if bark becomes dry, it is difficult to rewet. Ideally, bark beds should not become excessively dry between irrigations.

StONe FRUIT. Little is known about peach nutrition under Florida conditions. Most growers use soil and leaf tissue analyses along with plant vigor and appearance to evaluate their fertilizer programs. General annual $\mathrm{N}$ fertilizer guidelines for Florida peaches call for $\approx 100 \mathrm{lb} /$ acre $\mathrm{N}$ for mature trees with one-third applied before bloom and the remainder applied in late May, soon after harvest (Ferguson et al., 2007). If trees appear $\mathrm{N}$-deficient, or growth is not vigorous, a small amount of $\mathrm{N}$ (15 to $20 \mathrm{lb} /$ acre) is recommended in early August. However, preliminary data suggest that current annual $\mathrm{N}$ recommendations of $\approx 100 \mathrm{lb} / \mathrm{acre}$ may not be adequate (Wert, 2006) when only two or three applications of dry, granular fertilizer are made on sandy soils. Research is needed to determine if peaches respond positively to higher rates of $\mathrm{N}$ or to more frequent applications.

As a result of Florida's typically sandy soils with poor water-holding capacities, essentially all commercial stone fruit orchards in Florida are irrigated. Irrigation has been clearly shown to benefit peach production in the southeastern United States by increasing fruit size and uniformity and by increasing total yield (Taylor and Rieger, 2007). Water stress can be particularly devastating to peach during the last stage of fruit development known as "final swell" when the fruit attains $\approx 60 \%$ of its final size (Frecon, 2002). During this time, environmental conditions are such that ET is usually high and the tree's demand for water is great. Plum has a similar fruit development pattern. Drip irrigation systems are commonly used throughout the southeastern United States, but in Florida, where sandy soils predominate, microsprinklers are probably more effective than drip systems because of greater root zone coverage. A mature peach tree can use from 36 to $45 \mathrm{gal}$ of water in l d (Frecon, 2002; Taylor and Rieger, 2007). During I week, a mature orchard can use up to 1.7 inches of water (assuming 145 trees/acre). Young trees without well-established root systems are prone to drought injury and weak growth without irrigation. Most Florida peach orchards are irrigated with overhead or microsprinkler irrigation. Overhead irrigation has the advantage of protecting flowers and young fruit from late winter and early spring freezes, which are common throughout the peach production areas of Florida. Most growers do not use devices that directly monitor soil moisture content. Decisions on irrigation are largely based on crop phenology, rainfall, and other weather factors and appearance of the soil and plants.

Muscadine Grape. Muscadine fertilizer recommendations for established vineyards in the southeastern United States are generally $\approx 80$ to $140 \mathrm{lb} /$ acre $\mathrm{N}$ per year (Andersen et al., 2007; Braswell et al., 2006; Krewer et al., 2002). Little research is available on irrigation of muscadine; however, it is widely known that muscadine grapes respond favorably to irrigation and irrigation is essential for good vineyard establishment. Using drip microirrigation, NeSmith 
(2004) reported that daily rates of 6 to 8 gal per plant were sufficient for vigorous growth under Georgia conditions. With a plant density of 181 plants/acre, this would equal $\approx 1500$ gal/acre per day. In Florida, Andersen et al. (2007) recommends one drip emitter per plant during the establishment year and two additional emitters per plant thereafter. They recommend that $2 \mathrm{gal} /$ plant per day is sufficient during the first year and $12 \mathrm{gal} /$ plant per day should be satisfactory in subsequent years. Excess vine vigor from overfertilization is believed to reduce berry quality (Braswell et al., 2006).

Tropical/subtropical FRUIT. The nutrient and irrigation management for tropical and subtropical fruit crops varies by species and sometimes by cultivar. In general, major nutrients such as $\mathrm{N}, \mathrm{P}$, and $\mathrm{K}$ are applied in granular form or applied through a microirrigation system (fertigation). Secondary elements such as $\mathrm{Mg}$ and $\mathrm{S}$ are applied along with $\mathrm{N}-\mathrm{P}-\mathrm{K}$ or foliarly to the leaves. Microelements, including zinc, manganese, molybdenum, and boron, are commonly applied foliarly. Iron is applied in chelated form appropriate for high $\mathrm{pH}$, calcareous soils either as a soil drench or through fertigation.

Nutrient management may be based on previous research for some crops (e.g., avocado, carambola, and mango) but not others (e.g., guava, papaya, and sapodilla) or on recommendations from other production areas and extension/research faculty, fertilizer sales people, consultants, and grower experience (Table 1). The range in the rates of $\mathrm{N}, \mathrm{P}$, and $K$ applied among and within a particular fruit farming operation varies widely (Li et al., 1999). For example, the range in $\mathrm{N}, \mathrm{P}$, and $\mathrm{K}$ applied to mature avocado orchards ranged from 36 to 288,4 to 72 , and 36 to $288 \mathrm{lb} /$ acre, respectively (Table 2 ). The frequency of $\mathrm{N}-\mathrm{P}-\mathrm{K}$ applications ranged from two to six times per year.

Leaf and/or soil sampling is recommended as a basis for nutrient management, but only $\approx 19 \%$ of those responding to a recent survey used soil nutrient samples and depending on the fruit species, $29 \%$ to $50 \%$ used leaf analysis ( $\mathrm{Li}$ et al., 1999; Migliaccio et al., 2006). Fertilizer application methods vary from orchard to orchard with dry, granular applications of $\mathrm{N}, \mathrm{P}$, and $\mathrm{K}$ being the most common followed by $\mathrm{N}$ and $\mathrm{K}$ applied as fertigation (Li et al., 1999). Organic (including sludge) materials are applied by an estimated $60 \%$ of the growers and this is increasing as the cost of chemical fertilizers increases. Nutrient conservation practices reported by commercial fruit growers include monitoring weather conditions to avoid nutrient applications immediately preceding a rainfall event and using calibrated low-volume irrigation chemical injection (Migliaccio et al., 2006).

Widespread adoption of leaf sampling and phenological crop management would improve plant nutrient management of tropical and subtropical fruit crops and potentially reduce fertilizer rates and/or frequencies. Optimum leaf nutrient levels in Florida are known for avocado, 'Tahiti' lime, and mango and preliminary data are available for others. Nutrient uptake efficiency varies by species and in some cases by cultivar. In the future, long-term breeding or selection programs for rootstocks and/or cultivars that integrate crop yields, quality, and pest resistance along with nutrient uptake efficiency could potentially reduce the need for nutrient inputs.

Irrigation management varies widely among and within tropical/ subtropical fruit orchards ( $\mathrm{Li}$ et al., 2000). The surficial Biscayne aquifer is the main fresh water source and is commonly accessed through wells. A recent survey reported that over 50\% of these wells were capped and cased to prevent contamination from runoff (Muñoz-Carpena et al., 2003a). Nearly $67 \%$ of the growers report having some type of high-volume irrigation system (application rates 0.20 inches/acre/ha or greater), which may be used for freeze protection and/or irrigation. In contrast, over $75 \%$ of the growers reported using a microirrigation system (most commonly a microsprinkler) with the capability of applying fertilizer (fertigation). The reported method of irrigation management varied by producer and fruit crop with $\approx 48 \%$ of the growers reporting they used some type of soil moisture monitoring, $64 \%$ to $73 \%$ measured or monitored rainfall (e.g., Florida Automated Weather Network), 60\% monitored weather data for scheduling irrigation, and 44\% took crop phenology and appearance into account $(\mathrm{Li}$ et al., 2000; Muñoz-Carpena et al., 2003a, 2003b). Water conservation practices vary by grower (Migliaccio et al., 2006; Muñoz-Carpena et al., 2003 b). In recent surveys, growers reported $16 \%$ to $21 \%$ used droughttolerant fruit crops (e.g., sapodilla, mango), $75 \%$ or more used a lowvolume irrigation system (mostly microsprinkler), $10 \%$ used water meters to monitor water use, $26 \%$ to $50 \%$ used some type of soil moisture monitoring, $60 \%$ to $69 \%$ reported monitoring weather data, including rainfall, $20 \%$ had on-farm rain gauges, $40 \%$ to $43 \%$ monitored plant phenology, 53\% mulched trees, 24\% kept irrigation records, $72 \%$ irrigated mainly in the early morning or late evening, and 30\% used the South Dade Soil and Water Conservation District's Mobile Irrigation Laboratory to assess the efficiency of their irrigation system.

The three most common reasons cited by growers for practicing water conservation included water, financial, and time savings (MuñozCarpena et al., 2003b). Of these, water and financial savings were ranked equally. Development and implementation of evapotranspiration-crop factor-based irrigation scheduling could potentially reduce irrigation rates and frequency and potential leaching of plant nutrients. In conjunction, discovery and/or development of practical and economic soil moisture monitoring probes, a better understanding of crop phenology cycles, what they mean and how to use them, and integration with better weather data could further improve irrigation management.

\section{Future challenges}

Temperate Fruit. Most new blueberry plantings are equipped with microirrigation systems and grown in highly amended soils or in pine bark bed production systems. The performance of microirrigation systems under these conditions needs further study and evaluation. Currently it is not known if drip microirrigation will provide sufficient root zone coverage in pine bark beds or in sandy soils amended with pine bark. Similarly, various microsprinkler designs need to be evaluated and tested in current blueberry soil management systems. 


\section{WORKSHOP}

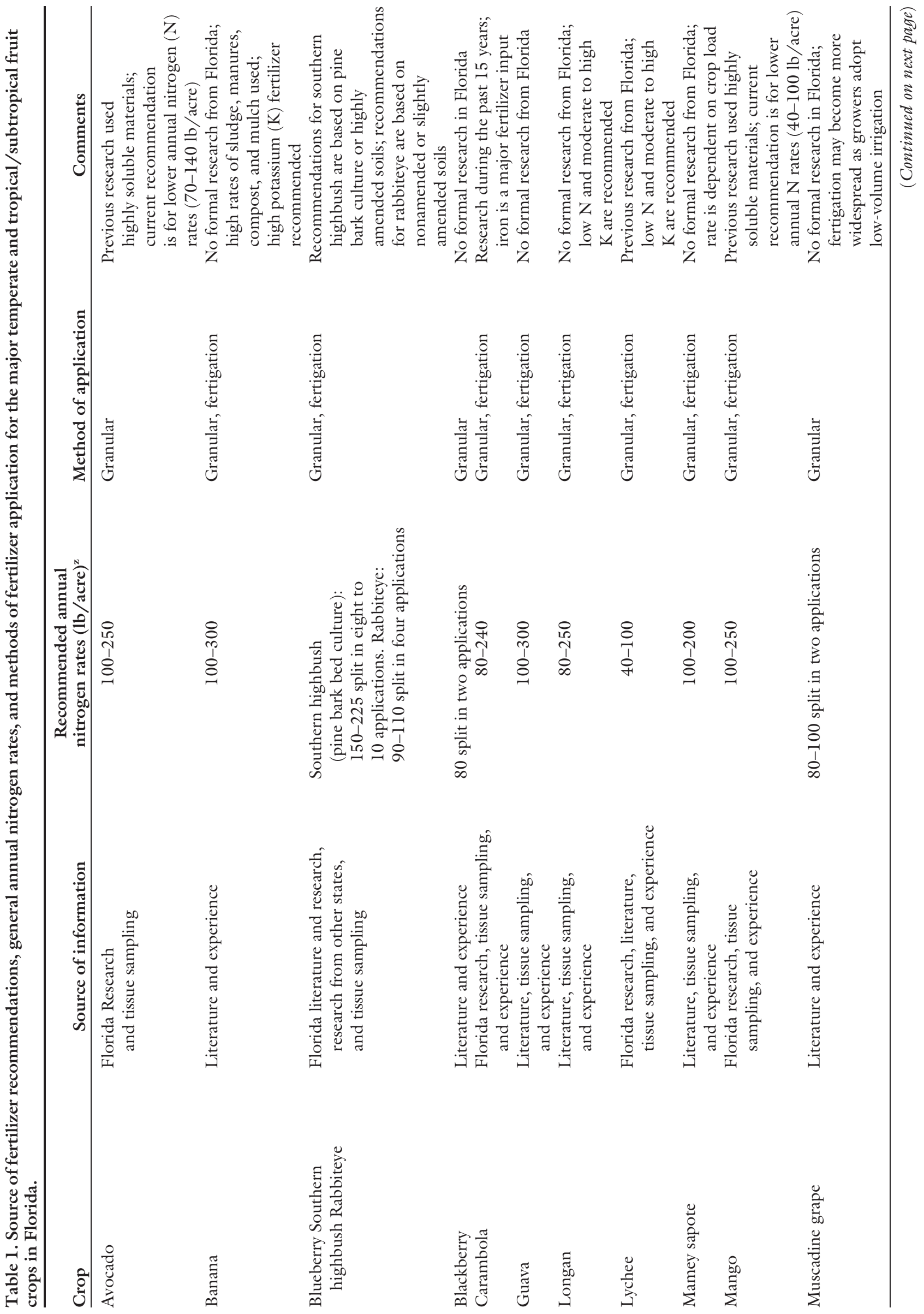




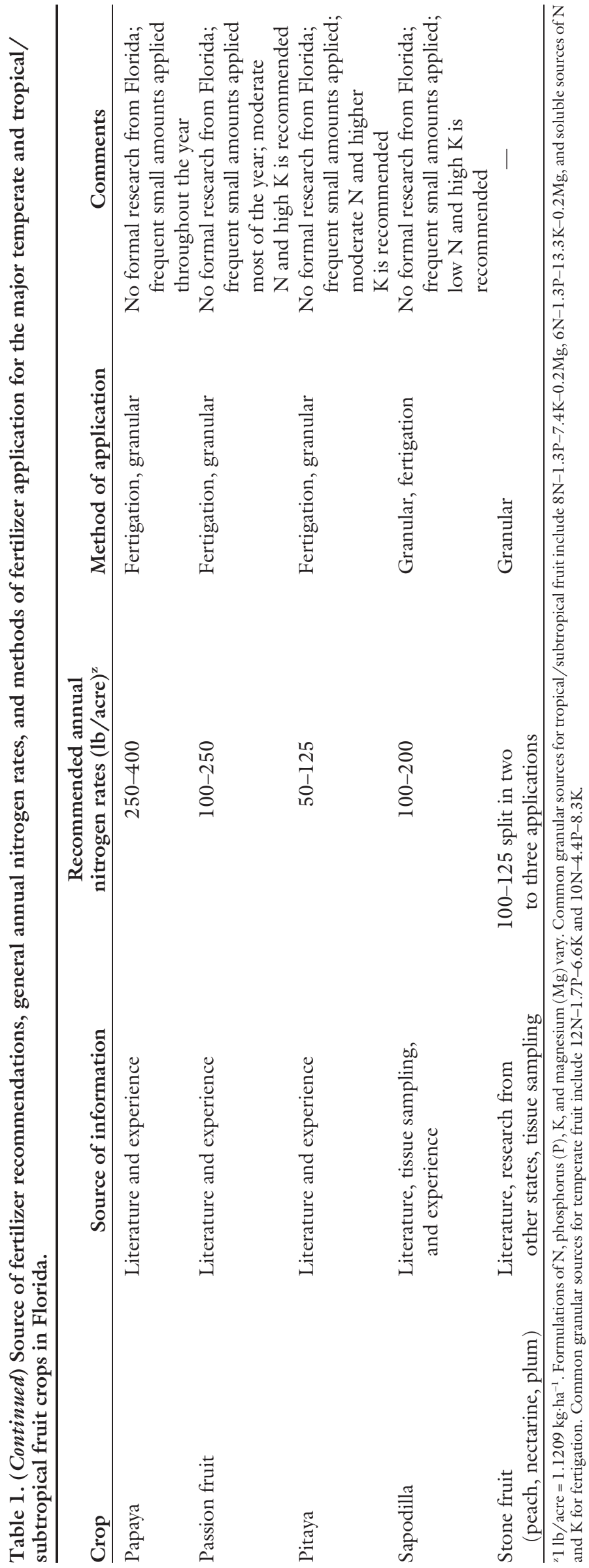

Management systems other than pine bark bed production need to be evaluated. Systems that would facilitate deeper rooting and require fewer inputs (such as organic matter, fertilizer, and water) would be desirable. Fertilizer (particularly $\mathrm{N}$ ) requirements need to be more clearly defined in pine bark culture systems and highly amended soils. Various slow- and controlled-release fertilizers need to be evaluated as a significant component of an overall nutritional program.

Blueberry water use and irrigation requirements under current management systems need to be determined, including development of a crop coefficient for mature SHB. Similarly, microirrigation technology for other temperate fruit crops needs to be further developed in terms of research and practical application. Adaptation of low-volume irrigation technology will allow for fertigation, which, if properly managed, will reduce fertilizer inputs by minimizing losses from leaching and/or runoff. Critical issues facing the temperate fruit industry include limited land availability, availability of sufficient water, especially during critical periods of high use such as during freeze events, and interfacing with the urban sector.

Tropical and sUbTropical FRUIT. Improvements in nutrient and irrigation management greatly reduce the potential for leaching of nutrients into the groundwater. Improvements in pest management continue to reduce potential negative environmental impacts. Research should be focused on developing and/or refining leaf nutrient standards (especially for $\mathrm{N}-\mathrm{P}-\mathrm{K}$ ) for selected tropical/subtropical fruit crops, e.g., banana, carambola, guava, mamey sapote, papaya, and sapodilla. Irrigation research should focus on refining and or developing ET/crop factors for use in scheduling irrigation and identifying practical and economic soil moisture monitoring equipment.

Critical issues include reducing production costs and development and use of sustainable cultural practices. Development of value-added products (e.g., sliced carambola, organically produced bananas), alternative markets (e.g., ethnic, local/ organic), and marketing are critical to the economic sustainability of the industry. Although land availability and 
Table 2. Reported annual nitrogen, phosphorus, and potassium fertilizer rates and application frequencies for selected bearing tropical fruit crops in Florida (from Li et al., 1999).

\begin{tabular}{lcccc}
\hline & \multicolumn{3}{c}{ Annual fertilizer application rates $(\mathbf{l b} / \text { acre })^{\mathrm{z}}$} \\
\cline { 2 - 5 } Crop & Nitrogen & Phosphorus & Potassium & $\begin{array}{c}\text { Applications } \\
\text { (no./yr) }\end{array}$ \\
\hline Avocado & $36-288$ & $2-32$ & $30-239$ & $2-6$ \\
Mango & $54-288$ & $0-32$ & $159-239$ & $2-3$ \\
Carambola & $8-445$ & $0-73$ & $0-416$ & $1-6$ \\
Lychee & $24-320$ & $5-157$ & $20-299$ & $1-8$ \\
Longan & $5-242$ & $6-40$ & $34-227$ & $1-6$ \\
\hline
\end{tabular}

${ }^{2} 1 \mathrm{lb} / \mathrm{acre}=1.1209 \mathrm{~kg} \cdot \mathrm{ha}^{-1}$.

cost are issues, tropical fruit acreage has been increasing, not decreasing, as the popularity of "estate" farming increases and conversion of vegetable fields to nurseries or orchards continues.

\section{Literature cited}

Andersen, P.C., T.E. Crocker, and J. Breman. 2007. The muscadine grape. Univ. Florida Coop. Ext. Serv. Publ. HS763.

Andersen, P.C., J.G. Williamson, and T.E. Crocker. 2000. Sustainability assessment of fruit crops for north and northcentral Florida. Univ. Florida Coop. Ext. Serv. Publ. HS765.

Bradner, A., B.F. McPherson, R.L. Miller, G. Kish, and B. Bernard. 2004. Quality of ground water in the Biscayne aquifer in Miami-Dade, Broward, and Palm Beach Counties, Florida, 1996-1998, with emphasis on contaminants. U.S. Geological Survey Open-File Rpt. 2004-1438, 1-20.

Braswell, J., J.M. Spiers, and C.P. Hegwood. 2004. Establishment and maintenance of blueberries. Mississippi State Univ. Coop. Ext. Serv. Publ. 1778.

Braswell, J., J.S. Stringer, B. Sampson, and D. Ingram. 2006. Establishment and production of muscadine grapes. Mississippi State Univ. Coop. Ext. Serv. Publ. 2290.

Brightwell, W.T. and M.E. Austin. 1980. Rabbiteye blueberries. Georgia Agr. Expt. Sta. Res. Bul. 259.

Darnell, R.L. and J.G. Williamson. 1997. Feasibility of blueberry production in warm climates. Acta Hort. 446:265-269.

Degner, R.L., T.J. Stevens, and K.L. Morgan. 2002. Miami-Dade County agricultural land retention study. Florida Agr. Market Res. Ctr., Univ. Florida. Vol. 3, Appendix B. p.16.

Dourte, D.R. 2007. Crop water requirements and irrigation management. MS Thesis. Univ. Florida, Gainesville, FL.
Edwards, E. 2005a. Marginal analysis: An economic procedure for selecting alternative technologies/practices. Univ. Florida Coop. Ext. Serv. Publ. FE565.

Edwards, E. 2005b. Florida avocado production and profitability analysis. Univ. Florida Coop. Ext. Serv. Publ. FE575.

Edwards, E. 2008. Commodity analysis, fruits. Agricultural economics-Fruit crops. 5 June 2008. <http://agecon-trec. ifas.ufl.edu/CommoditiesFruit.htm>.

Edwards, E., R. Degner, and K. Morgan. 2008a. Six ways to improve the profitability of lychee in south Florida. Univ. Florida Coop. Ext. Serv. Publ. FE497.

Edwards, E., R. Degner, J. Crane, R Rafie, and C. Balerdi. 2008b. Is it still profitable to grow lychee in Florida. Univ. Florida Coop. Ext. Serv. Publ. FE496.

Ferguson, J.J., J. Chaparro, J.G. Williamson, R.E. Rouse, and R.M. Mizell. 2007. Florida subtropical peaches: Production practices. Univ. Florida Coop. Ext Serv. Publ. HS1109.

Frecon, J.L. 2002. Best management practices for irrigation peach trees. Rutgers Univ. Coop. Ext. Serv. 2 May 2008. <http://njaes.rutgers.edu/drought/ pdfs/peachtreebmp.pdf>

Himelrick, D., A.A. Powel, and W.A. Dozier. 1995. Commercial blueberry production guide for Alabama. Auburn Univ. Coop. Ext. Serv. Publ. ANR-904.

Holzapfel, E.A., R.F. Hepp, and M.A Marino. 2004. Effect of irrigation on fruit production in blueberry. Agr. Water Mgt. 67:173-184.

Krewer, G., M. Hall, D.S. Nesmith, D. Horton, H. Sherm, P. Summer, T. Tyson, and G. Wesberry. 2002. Georgia muscadine production guide. 15 Mar. 2008. <http://www.smallfruits.org/Muscadines/production/02muscad.pdf $>$.

Krewer, G. and D.S. Nesmith. 2004. Blueberry fertilization in soil. 15 Mar. 2009. <http://www.smallfruits.org/Blueberries/production/blueberryfert.pdf $>$.
Krewer, G. and J. Ruter. 2005. Fertilizing highbush blueberries in pine bark beds. 15 Mar. 2009. <http://pubs.caes.uga. edu/caespubs/pubs/PDF/B1291.pdf>.

Li, Y., J. Crane, B. Boman, and C. Balerdi. 1999. Fertilizer management survey for tropical fruit crops in south Florida. Proc. Florida State Hort. Soc. 112: 172-176.

Li, Y., J. Crane, B. Boman, and C. Balerdi. 2000. Irrigation management survey for tropical fruit crops in south Florida. Proc. Florida State Hort. Soc. 113:40-42.

Lyrene, P.M. and J.G. Williamson. 2006. Protecting blueberries from freezes in Florida, p. 21-25. In: N.F. Childers and P.M. Lyrene (eds.). Blueberries: For growers, gardeners and promoters N.F. Childers Horticultural Publications, Gainesville, FL.

Migliaccio, K.W. 2007. Sustainability of agriculture in Miami-Dade County: Considering water supply, AE429. Univ. Florida, Coop. Ext. Serv. Publ. AE429.

Migliaccio, K.W., J.H. Crane, E. Edwards, B. Schaffer, Y. Li, and R. Muñoz-Carpena. 2006. South Florida tropical fruit grower perspectives: Water conservation management practices. Univ. Florida Coop. Ext. Serv. Publ. ABE368.

Muñoz-Carpena, R., J.H. Crane, G.D. Israel, and C. Yurgalevitch. 2003a. Water conservation survey of Miami-Dade County agricultural and golf course commercial water users. Proc. Florida State Hort. Soc. 116:15-21.

Muñoz-Carpena, R., J.H. Crane, G.D. Israel, and C.F. Balerdi. 2003b. Tropical fruit growers' water use and conservation practice in Miami-Dade County. Univ. Florida Coop Ext. Serv. Publ. ABE345.

NeSmith, D.S. 2004. Drip irrigation, muscadines. 15 Mar. 2009. <http:// www.smallfruits.org/Newsletter/Vol4Issue4.pdf>.

Obreza, T.A., J.G. Williamson, R.L. Darnell, and P.M. Lyrene. 1998. Performance of a young southwest Florida nondormant blueberry planting. Proc. Florida State Hort. Soc. 110:175-177.

Taylor, K.C. and M. Rieger. 2007. Irrigation scheduling. 15 Mar. 2009. <http://www.ent.uga.edu/Peach/ peachhbk/cultural/irrigation_sch.pdf>.

Tropical Research and Education Center. 2005. Tropical Research and Education Center strategic plan 2005: Providing excellence in tropical horticulture and natural resources research, extension, and teaching. 6 May 2008. <http://trec. ifas.ufl.edu/about_us.shtml>. 
U.S. Department of Agriculture. 2008. Noncitrus fruits and nuts preliminary summary, Jan. 2008. 10 Mar. 2009. <http://usda.mannlib.cornell.edu/usda/ current/NoncFruiNu/NoncFruiNu-0123-2009_revision.pdf>.

U.S. Department of Agriculture. 2009. 2007 Census of agriculture, FloridaState and county data, volume 1: Graphic area series, part 9. 10 Apr. 2009. <http:// www.agcensus.usda.gov/Publications/ 2007/Full_Report/Volume_1,_Chapter_ 1_State_Level/Florida/flv1.pdf>.

U.S. Environmental Protection Agency. 1989. Environmental Protection Agency,
National primary and secondary drinking water standards; Proposed rule. 40 CFR Parts 141, 142, and 143. U.S. Environ. Protection Agency, Washington, DC.

Wert, T.W. 2006. Evaluation of four lowchill peach cultivars in three climatic zones in Florida. MS Thesis. Univ. Florida, Gainesville, FL.

Williamson, J.G., G. Krewer, G. Pavlis, and C.M. Mainland. 2006. Blueberry soil management, nutrition and irrigation, $\mathrm{p}$. 60-74. In: N.F. Childers and P.M. Lyrene (eds.). Blueberries: For growers, gardeners and promoters. N.F. Childers Horticultural Publications, Gainesville, FL.
Williamson, J.G. and P.M. Lyrene. 1995. Commercial blueberry production in Florida. Univ. Florida Coop. Ext. Serv. Publ. SP-179.

Williamson, J.G., P.M. Lyrene, and E.P. Miller. 2000. A survey of blueberry acreage in Florida. Proc. Florida State Hort. Soc. 113:24-25.

Williamson, J.G. and E.P. Miller. 2009. Effects of fertilizer rate and form on vegetative growth and yield of southern highbush blueberry in pine bark culture. Hort Technology 19:152-157. 